\title{
Endocrinology of sociality: comparisons between sociable and solitary individuals within the same population of African striped mice
}

\author{
Schoepf, I ; Schradin, C
}

\begin{abstract}
The social organization of species ranges from solitary-living to complex social groups. While the evolutionary reasons of group-living are well studied, the physiological mechanisms underlying alternative social systems are poorly understood. By studying group-living and solitary individuals of the same species, we can determine hormonal correlates of sociality without the problem of confounding phylogenetic factors. The African striped mouse (Rhabdomys pumilio) is a socially flexible species, which can be solitary or alternatively form complex family groups, depending on population density and the extent of reproductive competition. We predicted group-living striped mice to show signs of reproductive suppression and social stress, resulting in higher corticosterone but lower testosterone levels when compared to solitary-living individuals. To determine whether differences in social organization correlated with hormonal differences, we collected blood samples from free-living striped mice during four breeding seasons when we experimentally induced solitary-living in philopatric individuals by locally reducing population density. Striped mice that were group-living did not change their corticosterone or estosterone levels during the study, indicating that there was no temporal effect during the breeding season. Striped mice of both sexes had significantly lower corticosterone levels after switching from group- to solitary-living. Solitary males - but not solitary females - had higher testosterone levels than groupliving conspecifics. Our results suggest that group-living results in physiological stress and can induce reproductive suppression, at least in philopatric males. The switch to solitary-living may thus be a tactic to avoid reproductive competition within groups, and is associated with decreased stress hormone levels and onset of independent reproduction.
\end{abstract}

DOI: https://doi.org/10.1016/j.yhbeh.2013.04.011

Posted at the Zurich Open Repository and Archive, University of Zurich

ZORA URL: https://doi.org/10.5167/uzh-89373

Journal Article

Accepted Version

Originally published at:

Schoepf, I; Schradin, C (2013). Endocrinology of sociality: comparisons between sociable and solitary individuals within the same population of African striped mice. Hormones and Behavior, 64:89-94.

DOI: https://doi.org/10.1016/j.yhbeh.2013.04.011 
1 Schoepf, I. \& Schradin, C. 2013. Endocrinology of sociality: Comparisons between sociable and solitary

2 individuals within the same population of African striped mice. Hormones and Behavior, 64, 89-94.

\section{ABSTRACT}

4 The social organization of species ranges from solitary-living to complex social groups. While the

5 evolutionary reasons of group-living are well studied, the physiological mechanisms underlying

6 alternative social systems are poorly understood. By studying group-living and solitary

7 individuals of the same species, we can determine hormonal correlates of sociality without the

8 problem of confounding phylogenetic factors. The African striped mouse (Rhabdomys pumilio) is

9 a socially flexible species, which can be solitary or alternatively form complex family groups,

10 depending on population density and the extent of reproductive competition. We predicted group-

11 living striped mice to show signs of reproductive suppression and social stress, resulting in higher

12 corticosterone but lower testosterone levels when compared to solitary-living individuals. To

13 determine whether differences in social organization correlated with hormonal differences, we

14 collected blood samples from free-living striped mice during four breeding seasons when we

15 experimentally induced solitary-living in philopatric individuals by locally reducing population

16 density. Striped mice that were group-living did not change their corticosterone or testosterone

17 levels during the study, indicating that there was no temporal effect during the breeding season.

18 Solitary striped mice of both sexes had significantly lower corticosterone levels than individuals

19 that remained group-living. Solitary males - but not solitary females -had higher testosterone

20 levels than group-living conspecifics. Our results suggest that group-living results in

21 physiological stress and can induce reproductive suppression, at least in philopatric males. The

22 switch to solitary-living may thus be a tactic to avoid reproductive competition within groups, and

23 is associated with decreased stress hormone levels and onset of independent reproduction. 
25 Keywords: aggression; dispersal; social flexibility; philopatry; communal breeding; cooperative

26 breeding; alternative reproductive tactics; helper.

\section{INTRODUCTION}

Animals show a variety of different social organizations, ranging from species

30 that live solitarily to species that form complex social groups (Wilson, 2000). Solitary

31 and group-living species display distinct mating systems, which are believed to arise as a

32 consequence of differences in individuals' social interactions with their conspecifics

33 (Blumstein et al., 2010). The ecological and evolutionary reasons that cause individuals

34 to form and maintain social groups have been extensively studied (Koenig et al., 1992;

35 Emlen, 1995; Cahan et al., 2002), while the reasons of solitary-living have received less

36 attention (Schradin et al., 2012b). More recently, it has been shown that relaxed

37 ecological constraints (low population density) and high reproductive competition within

38 groups favor solitary-living (Schradin et al., 2010; Schoepf and Schradin, 2012a),

39 supporting previous findings (Koenig et al., 1992) and theory (Emlen, 1995). In

40 comparison, the underlying physiological mechanisms that lead to different forms of

41 social systems are still poorly understood.

42 Many studies of the proximate mechanisms of sociality have focused on the

43 neuroendocrine system (Pfaff, 2005; Schoech et al., 2004). Hormone levels can change in

44 a relative short period of time (Wynne-Edwards and Reburn, 2000) and, by acting

45 directly in the brain and on the peripheral organs, play a prominent role in affecting an

46 individual's behavior (Buntin, 1996). Glucocorticoids (e.g. corticosterone) are important

47 modulators of stress responses as they allow individuals to react to energetically

48 demanding situations, such as those encountered during social interactions, dispersal and 
49 when exploring novel environments (Belthoff and Dufty, 1998; Creel, 2001; Young and

50 Monfort, 2009). Androgens (e.g. testosterone) are strong modulators of reproduction,

51 dominance and aggression (Moore et al., 1998; Evans et al., 2000). Most of the

52 endocrinological research on sociality has thus far focused on comparing dominants and

53 subordinates within the same group (Poiani and Fletcher, 1994; Carlson et al., 2004;

54 Malueg et al., 2009) or on the role of hormones in group stability (Sapolsky, 1992) and

55 intraspecific encounters (Marler et al., 1995). What is so far mainly missing are

56 comparisons between solitary and group-living individuals. Solitary and group-living

57 species are expected to differ in the way they react to environmental limitations, yet

58 comparisons of physiological mechanisms of solitary and group-living species are very

59 rare and difficult to interpret because of confounding phylogenetic effects (Beery et al.,

60 2008). Studies on endocrine factors of dispersal (Nunes et al., 1999) are problematic as in

61 most social species individuals are solitary only during the dispersal phase and do not

62 follow a permanent solitary tactic. These problems could be avoided by studying the

63 physiological profiles of socially flexible species.

64 In socially flexible species, both group-living and solitary individuals occur in the

65 same population, and even the entire social organization of a population can switch from

66 group- to solitary-living as a response to environmental changes (Schradin et al., 2012b).

67 Social flexibility has been observed in several species of insects, birds and mammals

68 where both males and females are able to change their social and reproductive tactics in

69 response to changing environmental conditions (Schradin et al., 2012b). Studies of

70 species with alternative reproductive tactics indicate that individuals following different

71 tactics differ in their steroid hormone levels (Oliveira et al., 2008). Males following a 
72 dominant bourgeois tactic also often have the highest androgen levels (Rose et al., 1971;

73 Bartsch et al., 1992; Gould, 2005), whereas glucocorticoid patterns are not as clear

74 because subordinate individuals of some species show high glucocorticoid levels (Creel,

75 2005), whereas in other species, individuals following a dominant tactic have the highest

76 glucocorticoid levels (Creel, 2001). Nonetheless, individuals following alternative

77 reproductive tactics differ in their hormone profile, and we can thus expect hormonal

78 differences also between group-living and solitary individuals of the same species.

79 The African striped mouse (Rhabdomys pumilio) is a highly socially flexible

80 species, and thus makes for an ideal model to study whether individuals that are solitary

81 differ in their hormone profile from individuals that are group-living. When population

82 density is high, striped mice live in extended family groups, consisting of a breeding

83 male, two to four communally breeding females and their adult philopatric offspring of

84 both sexes (Schradin and Pillay, 2004). Individuals of both sexes can become solitary if

85 population density becomes low during the breeding season (Schradin et al., 2010;

86 Schoepf and Schradin, 2012a). Striped mice of both sexes are thus able to follow one of

87 three alternative reproductive tactics: (i) remain as non-breeding philopatrics in their natal

88 nest; (ii) become dominant group-living breeders; or (iii) disperse and become solitary-

89 living breeding females or solitary roaming males (Schradin and Pillay, 2003, Schradin,

90 2004). Corticosterone levels of non-breeding philopatric striped mice are seven times

91 higher than those of breeding males during the breeding season, but these levels drop in

92 the following non-breeding season (Schradin, 2008), or when males are removed from

93 the family in captivity, indicating that philopatric males are reproductively suppressed

94 (Schradin et al. 2009b; Schradin et al 2012b). Intra-group competition over limited 
95 resources, such as food, can be high in group-living species (Danchin et al., 2008) and

96 may cause additional physiological stress, which might be reduced when group size

97 declines. Dispersal of siblings causes a decline of group size and might influence the

98 hormone profile of those individuals remaining within the group. We predicted: a) group-

99 living striped mice of both sexes that would later become solitary to have higher

100 corticosterone levels than their siblings which would remain group-living (i.e. high

101 corticosterone levels could trigger dispersal), b) corticosterone levels to decrease once

102 individuals have dispersed and have become solitary; and c) group-living individuals to

103 show lower corticosterone levels after group size declined due to the dispersal of other

104 group members.

105 Testosterone levels of male philopatrics are lower than those of roaming and

106 breeding males (Schradin et al., 2009a), and testosterone levels of all male and female

107 striped mice decrease from the breeding to the non-breeding season (Schradin, 2008).

108 Testosterone promotes sexual motivation and suppresses parental care in males

109 (Wingfield et al., 1990; Ketterson and Nolan, 1999; Wingfield et al., 2001). Philopatric

110 striped mice act as helpers at the nest and show high degrees of alloparental care, whereas

111 solitary-living roaming males do not participate in parental care (Schradin et al., 2009a).

112 Testosterone has been associated with aggression in males (Wingfield et al., 1990) and in

113 many vertebrate species females can be as aggressive as males (Hau, 2007), including

114 striped mice, in which individuals of both sexes are more aggressive when they become

115 solitary than when they are group-living (Schoepf and Schradin, 2012b). In addition,

116 testosterone is anxyolytic in laboratory mice (Aikey et al., 2002) and might promote risk-

117 taking in roaming male striped mice (Schradin et al., 2009b). Female striped mice can 
118 either breed communally or solitarily, with solitary-breeding likely to be the riskier tactic,

119 since solitary breeders must find and defend a territory alone. Thus, testosterone in

120 females might play a similar role as in males in promoting risk-taking behaviors. We

121 predicted: a) testosterone levels of solitary individuals of both sexes to be higher than of

122 group-living individuals; and b) testosterone levels of males and females that would later

123 disperse to be higher than those of individuals that would remain group-living, indicating

124 their readiness to seek independent breeding.

126 METHODS

127 Study period and field techniques

128 Data were collected during the breeding season (August to November) of 2007-2010 on a

129 field site located on the farm Klein Goegap (29² $\left.42.30^{\prime} \mathrm{S}-18^{\circ} 02.95^{\prime} \mathrm{E}\right)$ near the town of

130 Springbok in South Africa. Striped mice social tactics (solitary or group-living) were

131 determined using a combination of trapping, radio-tracking and behavioral observations

132 (Schradin et al., 2010; Schoepf and Schradin, 2012). Striped mice were trapped at their

133 nest, sexed, weighed and marked permanently with ear-tags (National Band and Tag Co.,

134 Newport, KY, U.S.A.) and temporarily with a non-toxic hair dye (Inecto Rapido,

135 Pinetown, South Africa) for individual recognition during behavioral observations. All

136 adult breeders and up to four philopatrics (two females and two males) of each group

137 were fitted with radio-collars (Holohil, Carp, Ontario, Canada; $1.2-4.5 \mathrm{~g}$ ). Striped mice

138 were radio-tracked during the day to determine home ranges and at night to determine

139 composition of sleeping groups, following the methods previously established by

140 Schradin and Pillay (2005). Striped mice that spent more than $75 \%$ of the nights with 
141 other individuals were regarded as group-living whereas those that slept alone for $>75 \%$

142 of the nights were regarded as solitary-living; no intermediate values occurred. All mice

143 sampled were part of a field manipulation experiment in which we tested the role of

144 population density on sociality by removing several groups from the field site (Schoepf

145 and Schradin, 2012a). Removal of groups was carried out in the beginning of each

146 breeding season in the years 2007 to 2010. Altogether, 52 mice from 12 groups were

147 removed from a 30 hectares area (for more details see Schoepf and Schradin, 2012a).

148 Blood samples were obtained only from individuals belonging to groups that were not

149 removed.

151 Collection and analysis of blood samples

152 Striped mice were captured directly at their nests in the early morning (between 06:15

153 and 8:30 depending on sunrise) within 30min after they emerged. Mice were

154 anaesthetized with diethyl ether and blood samples were collected from a sublingual vein

155 (Heimann, 2006). All samples were obtained within three minutes after a mouse had

156 entered the traps to avoid a stress response (Schradin, 2008). Samples were transported to

157 the research station, where they were left to clot at room temperature (for up to $1.5 \mathrm{~h}$ from

158 the time the sample was taken; ambient temperature was mainly below $20 \mathrm{C}$ during the

159 breeding season). Samples were centrifuged for 10 minutes and the obtained serum

160 (extracted in different aliquots: $20 \mu \mathrm{l}$ for corticosterone and $60 \mu \mathrm{l}$ for testosterone) was

161 stored at -20 C. All samples were analyzed at the University of Zurich, using enzyme

162 immuno-assays. Corticosterone and testosterone levels were measured with commercial

163 kits from IBL Hamburg, following procedures previously validated for striped mice 
164 (Schradin, 2008). Coefficients for intra-assay variation were 7.8\% for testosterone and

$16511.1 \%$ for corticosterone. Coefficient for inter-assay variation was $10.2 \%$ for testosterone

166 and $10.9 \%$ for corticosterone. 30 samples from group-living mice and 30 samples from

167 solitary mice were analyzed for corticosterone, and 27 samples from group-living

168 individuals and 30 samples from solitary individuals were analyzed for testosterone

169 (Table 1). Blood samples were obtained an average of $8.55 \pm 5.25$ days before individuals

170 switched from group-living to solitary and an average of $9.78 \pm 5.77$ days after

171 individuals had become solitary. Six individuals (four females and two males) were re-

172 sampled after switching from group-living to solitary. We waited $16.00 \pm 3.94$ days

173 before taking blood from the same individual. All individuals used in the study were

174 initially philopatrics, born from the first litter of the breeding season and, thus, of similar

175 age and body mass when sampled. The study obtained ethical clearance from the

176 University of the Witwatersrand (AESC: 2007/38/04).

178 Data analysis

179 Data analysis was performed using the statistical software R (version 2.11.0 R

180 Development Core Team 2006). Data were tested for normality using the Shapiro-Wilk

181 Normality Test and are presented as mean \pm standard deviation. Exact $p$-value

182 calculations were performed on all tests. We used generalized linear models (GLM) to

183 compare: 1. group-living mice that remained so, with mice that would become solitary-

184 living, before the latter dispersed; and 2. group-living and solitary-living individuals after

185 the latter had dispersed and became solitary. The first GLM was used to test whether

186 striped mice that would later become solitary already differed hormonally from striped 
187 mice that remained group-living before dispersal. The second GLM tested whether 188 group- and solitary-living individuals differed in hormone levels after dispersal. Each

189 GLM had one of the hormones (corticosterone or testosterone) as the response variable;

190 while sex or social category (group-living or solitary) were the fixed factors. We used

191 linear mixed effect models (LMM) to compare: (i) striped mice that became solitary-

192 living, before and after dispersal; and (ii) striped mice that remained group-living, before

193 and after the dispersal of some of their group members. The first LMM was used to test

194 whether striped mice change their hormone levels when they change social tactic. The

195 second LMM was used to test whether hormone levels of group-living individuals might

196 change following the departure of some of their group members even though their social

197 tactic does not change. Each LMM had one of the two hormones as the response variable,

198 sex and social category as the fixed factors and individual ID as a random factor to

199 account for pseudo-replication. We selected the best model by a stepwise backward

200 procedure (following Crawley, 2007). Hormone levels were square-rooted prior to

201 analyses owing to their skewed distribution. We used LMMs and GLMs to compare

202 hormone levels between subjects and paired t-tests to compare hormone levels within the

203 same individuals before and after they became solitary.

205 RESULTS

206 Differences in hormone levels permanently group-living striped mice and group-living

207 striped mice that later became solitary-living

208 Group-living striped mice males that would later become solitary displayed a trend

209 towards having lower corticosterone levels than males that would remain group-living 
210 (GLM: $F_{1,9}=4.6, p=0.06$; Fig. 1a). Group-living striped mice females that would later

211 become solitary did not differ in their corticosterone levels from females that remained

212 group-living (GLM: $F_{1,16}=0.48, p=0.50$; Fig. 1a). Dispersing males' corticosterone

213 levels were significantly lower than those of dispersing females (GLM: $F_{1,9}=6.73, p=$

214 0.029; Fig. 1a), whereas corticosterone levels of striped mice males and females that

215 remained group-living did not differ (GLM: $F_{1,16}=0.43, p=0.52$; Fig. 1a).

216 Group-living striped mice males that would later become solitary did not differ in

217 their testosterone levels from males that would remain group-living (GLM: $F_{1,7}=0.33, p$

$218=0.58$; Fig. 1b); and group-living striped mice females that would later become solitary

219 did not differ in their testosterone levels from females that would remain group-living

220 (GLM: $F_{1,11}=2.43, p=0.15$; Fig. 1b). Whereas dispersing males' testosterone levels did

221 not differ significantly from those of dispersing females (GLM: $F_{1,8}=0.13, p=0.72$; Fig.

222 1b), non-dispersing males had higher testosterone levels than non-dispersing females

223 (GLM: $F_{1,10}=9.62, p=0.01$; Fig. $\left.1 \mathrm{~b}\right)$.

225 Comparison of hormone levels between solitary individuals before and after they became

226 solitary

227 We compared hormone levels of mice that were group-living at the start of the

228 experiment but later became solitary (middle bars of Fig. 1) with hormone levels of

229 solitary mice at the end of the experiment (right bars in Fig. 1). Striped mice that were

230 group-living at the start of the experiment but later became solitary had significantly

231 higher corticosterone levels than solitary-living striped mice (at the start of the

232 experiment: $1437.85 \pm 832.44 v s$. at the end of the experiment: $575.62 \pm 497.13$; LMM: 
$\left.233 F_{1,5}=16.73, p=0.009\right)$. Specifically, males that were group-living at the start of the

234 experiment, but would later become solitary, had significantly higher corticosterone

235 levels than solitary-living males (GLM: $F_{1,14}=7.04, p=0.02$; Fig. 1a); and females that

236 were group-living at the start of the experiment, but would later become solitary, showed

237 a trend towards having higher corticosterone levels than solitary-living females (LMM:

$238 F_{1,3}=7.55, p=0.07$; Fig. 1a). Corticosterone levels of males were significantly lower

239 than females both at the start (GLM: $F_{1,9}=5.50, p=0.04$; Fig. $\left.1 \mathrm{a}\right)$ and at the end of the

240 experiment (GLM: $F_{1,18}=11.62, p=0.003$; Fig. 1a).

241 Male striped mice that were group-living at the start of the experiment but later

242 became solitary had significantly lower testosterone levels than solitary-living males

243 (GLM: $F_{1,14}=13.16, p=0.003$; Fig. 1b). Testosterone levels of females that were group-

244 living at the start of the experiment but later became solitary remained similar to those of

245 solitary-living females (LMM: $F_{1,3}=1.14, p=0.36$; Fig. $\left.1 \mathrm{~b}\right)$. While testosterone levels of

246 males that would become solitary did not differ from females that would become solitary

247 at the start of the experiment (GLM: $F_{1,8}=0.13, p=0.72$; Fig. 1b), solitary-living males

248 had significantly higher testosterone levels than solitary-living females (GLM: $F_{1,18}=$

249 23.51, $p<0.0001$; Fig. 1b).

250 In addition, we compared changes in hormone levels for six individuals (four

251 females and two males for corticosterone and three females and two males for

252 testosterone) for which we had samples when they were still in the group and after they

253 had become solitary (paired data). Striped mice that dispersed and adopted a solitary life

254 significantly decreased their corticosterone levels (before: $1427.59 \pm 1020.01$ vs. after:

$255664.74 \pm 681.68 ; t=2.28, d f=5, p=0.04)$. Testosterone levels increased considerably in 
both males (male 1 increased from $0.33 \mathrm{ng} / \mathrm{ml}$ to $5.55 \mathrm{ng} / \mathrm{ml}$ and male 2 increased from

$2570.80 \mathrm{ng} / \mathrm{ml}$ to $1.06 \mathrm{ng} / \mathrm{ml}$ ), and in three out of four females (from $0.37 \pm 0.41$ to $1.03 \pm$

258 1.17)

260 Hormonal adjustment in group-living individuals following dispersal of group members

261 Corticosterone levels of both group-living striped mice males and females remained

262 similar after the departure of some of their group members (males before: $1645.67 \pm$

263756.25 vs. after: $1504.82 \pm 780.39$; GLM: $F_{1,11}=0.02, p=0.89$; females before: 1426.00

$264 \pm 420.28 v s$. after: $\left.1382.29 \pm 622.40 ; \mathrm{LMM}: F_{1,3}=0.11, p=0.79\right)$.

265 Testosterone levels of group-living females showed a trend towards increasing

266 following the departure of some of their group-members (before: $0.19 \pm 0.20 \mathrm{vs}$. after:

$2670.60 \pm 0.52$; GLM: $F_{1,11}=4.30, p=0.06$ ), while testosterone levels of group-living males 268 remained similar even after the departure of some of their group members (before: $0.77 \pm$ $2690.45 v s$. after: $0.54 \pm 0.48$; GLM: $\left.F_{1,12}=1.03, p=0.33\right)$.

271 Differences in hormone levels between individuals that remained group-living and

272 individuals that became solitary after dispersal of the latter

273 Solitary striped mice males had significantly lower corticosterone levels than their

274 conspecifics that remained group-living (solitary: $301.12 \pm 304.22$ vs. group-living:

$2751382.29 \pm 622.40$; GLM: $\left.F_{1,16}=26.72, p<0.0001\right)$ and significantly higher testosterone

276 levels (solitary: $3.85 \pm 2.39 v s$. group-living: $0.54 \pm 0.48$; GLM: $F_{1,20}=30.31, p$

$277<0.0001)$. Solitary females had significantly lower corticosterone than females that

278 remained group-living (solitary: $791.11 \pm 356.87$ vs. group-living: $1504.82 \pm 780.39$; 
279 GLM: $\left.F_{1,11}=5.18, p=0.04\right)$, whereas they did not differ in their testosterone levels from 280 group-living females (solitary: $0.63 \pm 0.71 v s$. group-living: $0.60 \pm 0.52$; GLM: $F_{1,12}=$ $281 \quad 0.004, p=0.95)$.

DISCUSSION corticosterone levels than individuals that remained group-living, suggesting that

286 adopting a solitary tactic can be a way to avoid social stress arising from group-living.

287 Males that left their natal group to become solitary increased their testosterone levels but 288 not males that remained group-living. Females that became solitary showed a trend to 289 decrease their corticosterone levels, which, nonetheless, became significantly lower than 290 their cospecifics that remained group-living, but did not show an increase in their 291 testosterone levels. In a previous study, we demonstrated that males that dispersed were 292 scrotal while males that remained philopatric in their natal group were unscrotal; and that $29375 \%$ of females that dispersed, but only $13 \%$ of females that remained philopatric, were 294 breeding (Schoepf and Schradin, 2012a). Our results show that group-living males and 295 females differ considerably in their hormone profiles from solitary-living males and 296 females and indicate that hormone levels change when striped mice switch from group- to 297 solitary-living.

298 Glucocorticoids affect reproductive behavior by regulating the availability of 299 energy by influencing glucogenesis, fat and protein metabolism (Romero, 2002; Reeder 300 and Kramer, 2005). In some group-living birds and mammals, dominant individuals have 301 higher glucocorticoid levels than subordinates, while in other species dominants have 
302 lower levels. This difference might depend on whether it is more stressful to occupy a 303 dominant or a subordinate rank (Creel, 2001). One suggestion is that dominant 304 individuals suppress the reproduction of subordinates by inducing chronic stress, 305 resulting in sustained high levels of glucocorticoids in subordinates, the "physiological 306 castration" hypothesis (Abbott et al., 2003; Reyer et al. 1986). Our results taken together 307 with results from previous studies (Schradin ,2008; Schradin and Yuen, 2011; Schradin et 308 al., 2009b; Schradin et al ,20012b; Schradin et al, 2012c) indicate that this is the case in 309 philopatric male striped mice. Chronically increased glucocorticoid levels indicate 310 allostatic load, i.e. physiological costs due to an over activation of the neuroendocrine 311 stress response (McEwen and Wingfield, 2003). As a consequence, philopatric males 312 should leave their natal group when costs of dispersing to become solitary are lower than 313 costs of remaining philopatric. By reducing population density we experimentally offered 314 such option. In our study, corticosterone levels of solitary males only showed a trend 315 towards decreasing before these individuals changed from group-living to solitary. While 316 corticosterone levels of males became significantly much lower after individuals 317 switched from a social to a solitary tactic. The difference in corticosterone levels between 318 group-living and solitary individuals we found was much more marked than the 319 difference between individuals that were initially group-living but later became solitary 320 and individuals that remained group-living. Additionally, males that switched tactic were 321 already sexually mature before dispersal (Schoepf and Schradin, 2012a), which is in 322 agreement with the observation that high testosterone levels are not compatible with high 323 corticosterone levels in this species (Raynaud et al., 2012). 
After becoming solitary, females retained significantly higher corticosterone

325 levels than males, indicating important physiological differences between the sexes. In

326 mammals, breeding females need high glucocorticoid levels to deal with the energetic

327 demands of lactation and pregnancy (Reeder and Kramer, 2005), and in striped mouse

328 breeding females have high corticosterone levels (Schradin, 2008). Nevertheless, also in

329 female striped mice high corticosterone levels could be an indicator of stress, including

330 social stress, and our present study found that philopatric females that remained group-

331 living had higher corticosterone levels than females that became solitary. Most

332 importantly and, in contrast with philopatric males, philopatric females can breed in their

333 natal group when population density is low (Schradin et al. 2010). In an accompanying

334 study we showed that females that $75 \%$ of females that became solitary reproduced, but 335 only $13 \%$ of females that remained group-living bred (Schoepf and Schradin, 2012a).

336 Thus, increased corticosterone levels due to social stress could be one explanation why 337 young philopatric females often do not breed, but this needs further investigation, 338 particularly as our results showed that females that switched from group- to solitary-

339 living displayed only a trend toward decreasing their corticosterone levels. The situation

340 in females seems to be thus more complex than in males and further studies are needed to 341 elucidate it.

342 Dispersal of individuals from a group might affect others that remain in the group.

343 Dispersal of siblings has been shown to reduce competition over food and to increase

344 body condition in screech-owls (Otus asio and Otus kennicottii; Belthoff and Dufty,

345 1998). In our study, dispersal of group-members did not cause changes in corticosterone

346 levels in the individuals that remained group-living, suggesting that a decrease in group 
347 size did not decrease stress levels, supporting the idea that remaining as a non-breeding

348 helper within the group is stressful.

349 Group-living striped mice that later became solitary did not differ in their

350 testosterone levels from striped mice that would remain group-living. Testosterone levels

351 of philopatric males also remained similar before and after departure of some of their

352 group-members, suggesting that reproductive suppression by their father rather than other

353 factors, such as population density, is the cause of their retained low testosterone levels.

354 Testosterone levels of solitary males, however, significantly increased. Similarly,

355 previous research has shown that philopatric male striped mice that become solitary

356 roaming males increase their testosterone levels and decrease their corticosterone levels

357 (Schradin and Yuen, 2011). In males, testosterone has several functions, which among

358 others include the regulation of aggression, sexual behavior and dispersal (Ketterson and

359 Nolan, 1999; Wingfield et al., 2001; Nelson, 2005). Testosterone levels of solitary males

360 in our study were comparable to testosterone levels measured in solitary males following

361 a roaming tactic (Schradin et al., 2009a). Philopatric males normally have smaller testes

362 and lower sperm counts (Schradin et al., 2009b), as well as lower testosterone and higher

363 corticosterone levels than roaming males (Schradin et al., 2009a). Striped mice dispersed

364 to seek independent breeding opportunities as soon as free territories were made

365 experimentally available (Schoepf and Schradin, 2012a). While most philopatric males

366 are sexually suppressed, males that dispersed were already sexually mature (i.e. scrotal)

367 at the time of dispersal (Schoepf and Schradin, 2012a). Thus, physiological changes

368 might have been initiated already shortly before dispersal. However, our current study

369 demonstrates that these physiological changes did not occur before we manipulated the 
environment and made territories available. Thus, it is likely that an increase of

371 testosterone levels shortly before dispersal might trigger the switch from group- to

372 solitary-living.

373 Testosterone levels of females were very similar to testosterone levels of

374 philopatric males, independently of their dispersal status, and comparable to those shown

375 in a previous study (Schradin 2008). In contrast to males, female testosterone levels did

376 not increase significantly after dispersal and staid in a low but measurable range. One of

377 the many functions of testosterone is to promote sexual motivation in males (Ketterson

378 and Nolan, 1999; Wingfield et al., 1990), while its functions in female vertebrates are

379 poorly understood. Testosterone in female mammals may also, as it is in male, be

380 associated with dispersal (Holekamp et al., 1984; Nunes et al., 1999), and there are

381 increasing evidence, at least in some species, that in the absence of reproductive

382 suppression testosterone levels can become higher even in females (Lutermann et al., in

383 press). In our study, females that dispersed and became solitary had nearly double as high

384 testosterone levels as philopatric females, but this difference was not significant and

385 overall testosterone levels of solitary females were low. The lower testosterone levels in

386 females as compared to males might indicate that in female striped mice testosterone is

387 not as important in reproduction as it is for males. Like in males, females that became

388 solitary started breeding, while most females that remained philopatric did not (Schoepf

389 and Schradin, 2012a), providing evidence that other hormones rather than testosterone

390 might play an important role in dispersal (perhaps progesterone or estrogen which were

391 not studied here, due to the small amounts of serum available). Interestingly, females'

392 testosterone levels increased following the departure of some of their group-members, but 
393 did not become higher than those of females that became solitary-living, and, at the

394 moment, it is not clear whether the significant increase we observed has any biological

395 significance, especially as testosterone levels were still relatively low.

396 Our results revealed important insights into the physiological mechanisms

397 underlying the differences between group-living and solitary individuals. Dispersing

398 males had lower corticosterone levels than philopatric males. As breeding males need low

399 corticosterone levels to allow for high testosterone levels necessary for spermatogenesis

400 (Raynaud et al., 2012), this might indicate that these males were already physiologically

401 primed to disperse and start independent breeding. Corticosterone levels were much

402 lower in solitary striped mice of both sexes. High corticosterone levels indicate high

403 physiological and metabolic costs for group-living individuals. Solitary males had

404 significantly higher testosterone levels than group-living males, suggesting that they were

405 no longer reproductively suppressed. Ours is one of very few studies comparing hormone

406 levels between alternative social and reproductive tactics in both sexes. Taken together

407 with previously published results (see Schoepf and Schradin, 2012a, 2012b) our findings

408 indicate a link between environmental change, behavioral adaptation and underlining

409 physiological mechanisms, which result in significant fitness consequences.

\section{Acknowledgements}

412 We wish to thank the Department of Tourism, Environment and Conservation of the

413 Northern Cape for research permits. We are also thankful to S. Jacobson, owner of the

414 Farm Klein Goegap, for permitting us to conduct our experiments on his property and the

415 manager and staff of the Goegap Nature Reserve for their support. We are grateful to the 
416 manager of the Succulent Karoo Research Station, C.H. Yuen for his assistance and

417 support. We wish to thank Prof. N. Pillay, Y. Auclair, C. Bousquet, R. Furrer, J. Raynaud

418 for comments and two anonymous reviewers whose suggestions improved the

419 manuscript. The Swiss National Science Foundation (SNF 3100A0-120194), the Swiss

420 Academy of Natural Sciences (SCNAT) and the Swiss South African Joint Research

421 Programme (SSAJRPA) provided the funding necessary to carry out the project. The

422 study obtained ethical clearance from the University of the Witwatersrand (AESC:

$4232007 / 38 / 04)$.

424

425 REFERENCES

426 Abbott, D. H., Keverne, E. B., Bercovitch, F. B., Shively, C. A., Mendoza, S. P., Saltzman, W., Snowdon, C. T., Ziegler, T. E, Banjevic, M., Garland jr., T., Sapolsky, R. M. 2003. Are subordinate always stressed? A comparative analysis

Aikey, J. L., Nygby, J. G., Anmuth, D. M., James, P. J. 2002. Testosterone rapidly reduces anxiety in male house mice (Mus musculus). Horm. Behav. 42, 448-460.

432 Bartsch, S. S., Johnston, S. D., Siniff, D. B. 1992. Territorial behaviour and breeding frequency of male Weddell seals (Leptinychotes weddelli) in relation to age, size, and concentration of serum testostere and cortisol. Can. J. Zool. 70, 680-692.

435 Beery, A. K., Lacey, E. A., Francis, D. D. 2008. Oxytocin and vasopressin receptor distributions in a solitary and a social species of tuco-tuco (Ctenomys haigi and Ctenomys sociabilis). J. Comp. Neurol. 507, 1847-1859. 
Belthoff, J. R., Dufty jr., A. M. 1998. Corticosterone, body condition and locomotor activity: A model for dispersal in screech-owls. Anim. Behav. 55, 405--415.

Blumstein, D. T., Armitage, K. B. 1999. Cooperative breeding in marmots. Oikos 84, 369-382.

Blumstein, D. T., Ebensperger, L. A., Hayes, L. D., Vásquez, R. A., Ahern, T. H., Burger, J. R., Dolezal, A. G., Dosmann, A., González-Mariscal, G., Harris, B. N., Herrera, E. A., Lacey, E. A., Mateo, J., McGraw, L. A., Olazábal, D., Ramenofsky, M., Rubenstein, D. R., Sakhai, S. A., Saltzman, W., Sainz-Borgo, C., Soto-Gamboa, M., Stewart, M. L., Wey, T. W., Wingfield, J. C., Young, L. J. 2010. Toward an integrative understanding of social behavior: new models and new opportunities. Front. Behav. Neurosci,4, 1-9.

Buntin, J.D. 1996. Neural and hormonal controls of parental behaviour in birds. Adv. Study Behav. 25, 161-213.

Carlson, A. A., Young, A. J., Russell, A. F., Bennett, N. C., McNeilly, A. S., CluttonBrock, T. 2004. Hormonal correlates of dominance in meerkats (Suricata suricatta). Horm. Behav. 46, 141-150.

Cahan, S. H., Blumstein, D. T., Sundström, L., Liebig, J., Griffin, A. 2002. Social trajectories and the evolution of social behavior. Oikos 96, 206-216.

Crawley, M. J. 2007. The R Book. Chichester: John Wiley \& Sons Ltd.

Creel, S. 2001. Social dominance and stress hormones. TREE 16, 491-497.

Creel, S. 2005. Dominance, aggression, and glucocorticoid levels in social carnivores. J. Mammal. 86, 255-264. 
Danchin, E., Giraldeau, L.A., Wagner, R.H. 2008. Animal aggregations: hypothesis and controversies. In: Danchin, E., Giraldeau, L. A., Cezilly, F. (Eds.), Behavioural Ecology. Oxford University Press, Oxford, pp. 503-545..

Emlen, S. T. 1995. An evolutionary theory of the family. Proc. Natl. Acad. Sci. U.S.A. 92, 8092-8099.

Evans, M. R., Goldsmith, A. R., Norris, S. R. A. 2000. The effects of testosterone on antibody production and plumage coloration in male house sparrows (Passer domesticus). Behav. Ecol. Sociobiol. 47, 156-163.

Gould, L. 2005. Variation in fecal testosterone levels, intermale aggression, dominance rank and age during mating and post-mating periods in wild adult male ring-tailed limurs (Lemur catta). Am. J. Phys. Anthropol. Suppl. 40, 108.

Hau, M. 2007. Regulation of male traits by testosterone: implications for the evolution of vertebrate life histories. BioEssays 29, 133-144.

Heimann, M., Kasermann, H. P., Pfister, R., Roth, D. R., Burki, K., 2009. Blood collection from the sublingual vein inmice and hamsters: a suitable alternative to retrobulbar technique that provides large volumes and minimizes tissue damage. Lab. Anim. 43, 255-260.

Holekamp, K. E., Smale, L., Simpson, H. B., Holekamp, N. A. 1984. Hormonal influences on natal dispersal in free-living Belding's ground squirrels (Spermophilus beldingi). Horm. Behav. 18, 465-483.

Ketterson, E. D., Nolan jr., V. 1999. Adaptation, exaptation, and constraint: A hormonal perspective. Am. Nat. 154, S4-S25. 

150. females in cooperative mole-rat societies. Gen. Comp. Endocrinol. In press. expenditure due to increased territorial defense in male lizards after phenotypic manipulation. Behav. Ecol. Sociobiol. 37, 225-231.

Malueg, A. L., Walters, J. R., Moore, I. T. 2009. Do stress hormones suppress helper

McEwen, B. S., Wingfield J.C. 2003. The concept of allostasis in biology and biomedicine. Horm. Behav. 43, 2-15.

Moore, M. C., Hews, D. K., Knapp, R., 1998. Hormonal control and evolution of alternative male phenotypes: generalizations of models for sexual differentiation. Am. Zool. 38, 133-151.

Nelson, R. J. 2005. Introduction to Behavioral Endocrinology. 3rd ed. Sinauer, Sunderland.

500 Nunes, S., Duniec, T. R., Schweppe, S. A., Holekamp, K. E. 1999. Energetic and endocrine mediation of natal dispersal behavior in Belding's ground squirrels.

503 Oliveira, R.F., Canario, A.V.M., Ros, A.F.H., 2008. Hormones and alternative reproductive tactics in vertebrates. In: Oliveira, R.F., Taborsky, M., Brockmann, 

Cambridge, pp. 132-174.

507 Pfaff, D. 2005. Hormones, Brain, and Behavior, Vol. 5. Academic Press, Boston.

508 Poiani, A., Fletcher, T. 1994. Plasma levels of androgens and gonadal development of

509 breeders and helpers in the bell miner (Manorina melanophrys). Behav. Ecol.

$510 \quad$ Sociobiol. 34, 31-41.

511 Raynaud, J., Müller, K., Schradin, C. 2012. Experimental increase of testosterone levels

512 in free ranging male African striped mice, Rhabdomys pumilio enhances sexual

513 maturation. Gen. Comp. Endocrinol. 178, 108-115.

514 Reeder, D., Kramer, K. M. 2005. Stress in free-ranging mammals: integrating physiology, 515 ecology, and natural history. J. Mammal. 86, 225-235.

516 Reyer, H. U., Dittami, J. P., Hall, M.R., 1986. Avian helpers at the nest: are they psychologically castrated? Ethology 71, 216-228.

518 Romero, L. M. 2002. Seasonal changes in plasma glucocorticoid concentrations in free519 living vertebrates. Gen. Comp. Endocrinol. 128, 1-24.

520 Rose, R. M., Holaday, J. W., Bernstein, I. S. 1971. Plasma testosterone, dominance rank 521 and aggressive behaviour in male rhesus monkeys. Nature 231, 366-368.

522 Saltzman, W., Ahmeda, S., Fahimi, A., Wittwer, D. J., Wegner, F. H. 2006. Social suppression of female reproductive maturation and infanticidal behavior in cooperatively breeding Mongolian gerbils. Horm. Behav. 49, 527-537.

525 Sapolsky, R. M. 1992. Cortisol concentrations and the social significance of rank instability among wild baboons. Psychoneuroendocrinology 17, 701-709. 
Schoech, S. J., Reynolds, S. J., Boughton, R. K. 2004. Endocrinology. In: Koenig, W. D., Dickenson, J. (Eds.), Ecology and Evolution of Cooperative Breeding in Birds. Cambridge University Press, Cambridge, 128-141.

Schoepf, I., Schradin, C. 2012a. Better off alone! Reproductive competition and ecological constraints determine sociality in the African striped mouse (Rhabdomys pumilio). J. Anim. Ecol, 81, 649-656.

Schoepf, I., Schradin, C. 2012b. Flexibility in social behaviour and predispositions to change reproductive tactics in African striped mice (Rhabdomys pumilio). Animal Behaviour, doi: 10.1016/j.anbehav.2012.08.019

Schradin, C. 2004. Territorial defense in a group living solitary forager: who, where, against whom? Behav. Ecol. Sociobiol. 55, 439-446.

Schradin, C. 2008. Seasonal changes in testosterone and corticosterone levels in four social classes of a desert dwelling sociable rodent. Horm. Behav. 53: 573-579

Schradin, C., Pillay, N., 2003. Paternal care in the social and diurnal striped mouse (Rhabdomys pumilio): laboratory and field evidence. J. Comp. Psychol. 117, 317324.

Schradin, C., Pillay, N. 2004. The striped mouse (Rhabdomys pumilio) from the Succulent Karoo, South Africa: a territorial group-living solitary forager with communal breeding and helpers at the nest. J. Comp. Psychol. 118, 37-47.

Schradin, C., Pillay, N. 2005. Demography of the striped mouse (Rhabdomys pumilio) in the Succulent Karoo. Mammal. Biol. 70 (2), 84-92.

Schradin, C., Yuen, C. H. 2011. Hormone levels of male African striped mice change as they switch between alternative reproductive tactics. Horm. Behav. 60, 676-680. 
550 Schradin, C., Scantlebury, M., Pillay, N., König, B. 2009a. Testosterone levels in dominant sociable males are lower than in solitary roamers: physiological differences between three male reproductive tactics in a sociably flexible mammal. Am. Nat. 173, 376-388.

554 Schradin, C., Schneider, C., Yuen, C. H. 2009b. Age at puberty in male African striped mice: the impact of food, population density and the presence of the father. Funct. Ecol. 23, 1004-1013.

Schradin, C., Schneider, C., Lindholm, A. K. 2010. The nasty neighbour in the striped mouse (Rhabdomys pumilio) steals paternity and elicits aggression. Front. Zool. 7, 19.

560 Schradin, C., Konig, B., Pillay, N. 2010. Reproductive competition favours solitary living while ecological constraints impose group-living in African striped mice. J.

563 Schradin, C., Eder, S., ., Müller, K., 2012a. Differential investment into testes and sperm production in alternative male reproductive tactics of the African striped mouse (Rhabdomys pumilio). Horm. Behav. 61: 686-695. N. 2012b. Social flexibility and social evolution in mammals: a case study of the African striped mouse (Rhabdomys pumilio). Mol. Ecol. 21, 541-553.

569 Schradin, C., William, R., Krackow, S., Carter, C., 2012c. Staying put or leaving home: 570 endocrine, neuroendocrine and behavioral consequences in male African striped 571 mice. Horm Behav.available online. 
572 Wilson, O. E. 2000. Sociobiology: The New Synthesis. Harvard University Press, Cambridge, Massachusetts, USA.

574 Wingfield, J. C., Hegner, R. E., Dufty, A. M. jr., Ball, G. F. 1990. The "challenge 575 systems, and breeding strategies. Am. Nat. 136, 829-846.

577 Wingfield, J. C., Lynn, S. E., Soma, K. K. 2001. Avoiding the 'costs' of testosterone: ecological bases of hormone-behavior interactions. Brain Behav. Evol. 57, 239251.

580 Wynne-Edwards, K. E., Reburn, C. J. 2000. Behavioural endocrinology of mammalian fatherhood. TREE 15, 464-468.

582 Young, A. J., Monfort, S. L. 2009. Stress and the costs of extra-territorial movement in a 583 social carnivore. Biol. Lett. 5, 439-444. 


\section{TABLES AND FIGURES}

\section{Table 1.}

587 Total number of individuals sampled for corticosterone and testosterone throughout the

588 study. "Philopatric" indicate individuals that remained permanently group-living and

589 "Solitary" individuals that were originally group-living, but later became solitary.

590 Numbers in parenthesis indicate individuals that were sampled twice.

592 Figure 1.

593 Comparison of hormone levels between permanently group-living mice (labeled as

594 'Group-living'), group-living mice that later became solitary (labeled as 'Group-living $\rightarrow$

595 Solitary'), and, solitary-living mice (labeled as 'Solitary'). a) Corticosterone and b)

596 Testosterone. $\mathrm{p}^{*}<0.05 ; \mathrm{p}^{* *}<0.01 ; \mathrm{p}^{* * *}<0.001$ 
Table 1.

\begin{tabular}{|c|c|c|c|}
\hline \multicolumn{2}{|c|}{} & Before & After \\
\hline \multirow{3}{*}{ Corticosterone } & Philopatric & 18 & 12 \\
\cline { 2 - 4 } & Solitary & $11(6)$ & $19(6)$ \\
\hline \multirow{2}{*}{ Testosterone } & Philopatric & 12 & 15 \\
\cline { 2 - 4 } & Solitary & $10(5)$ & $20(5)$ \\
\hline
\end{tabular}

599

600 
$601 \quad$ Figure 1.

602 a)

\section{Corticosterone levels}

aMales $\mathbf{a}$ Females

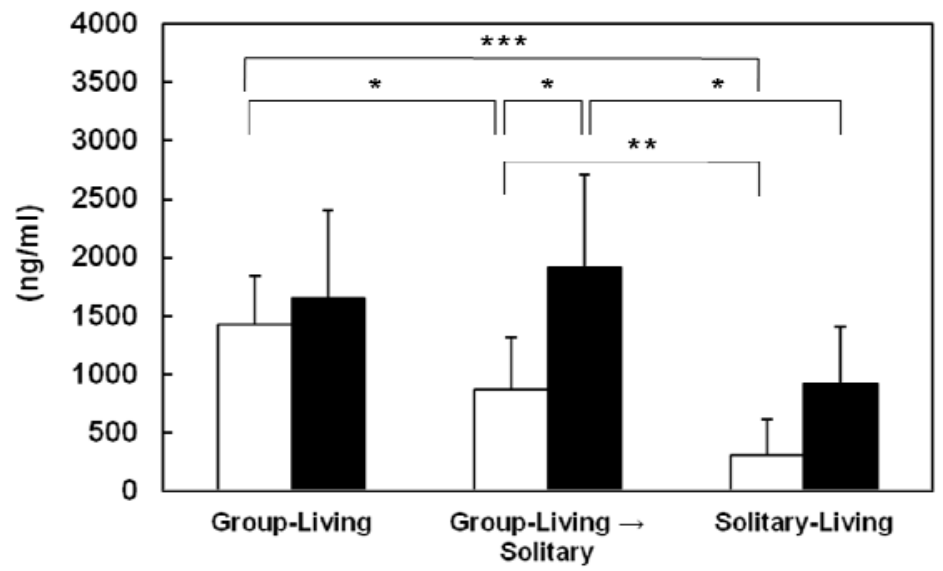

603

604 b)

\section{Testosterone levels}

aMales $\mathbf{a}$ Females

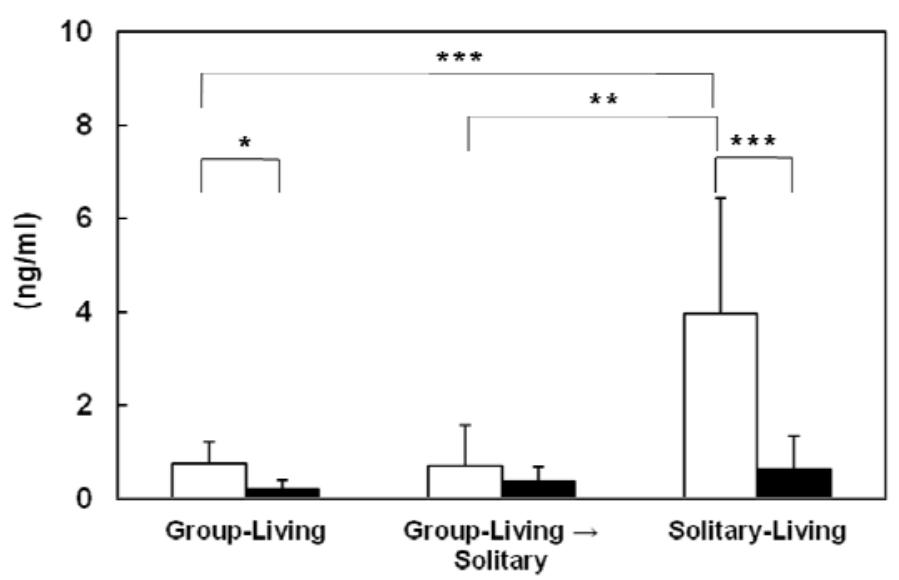

605 